\title{
Population Ecology
}

\section{Population ecology and egg laying strategy in the 'cruciata' ecotype of the endangered butterfly Maculinea alcon (Lepidoptera: Lycaenidae) \\ --Manuscript Draft--}

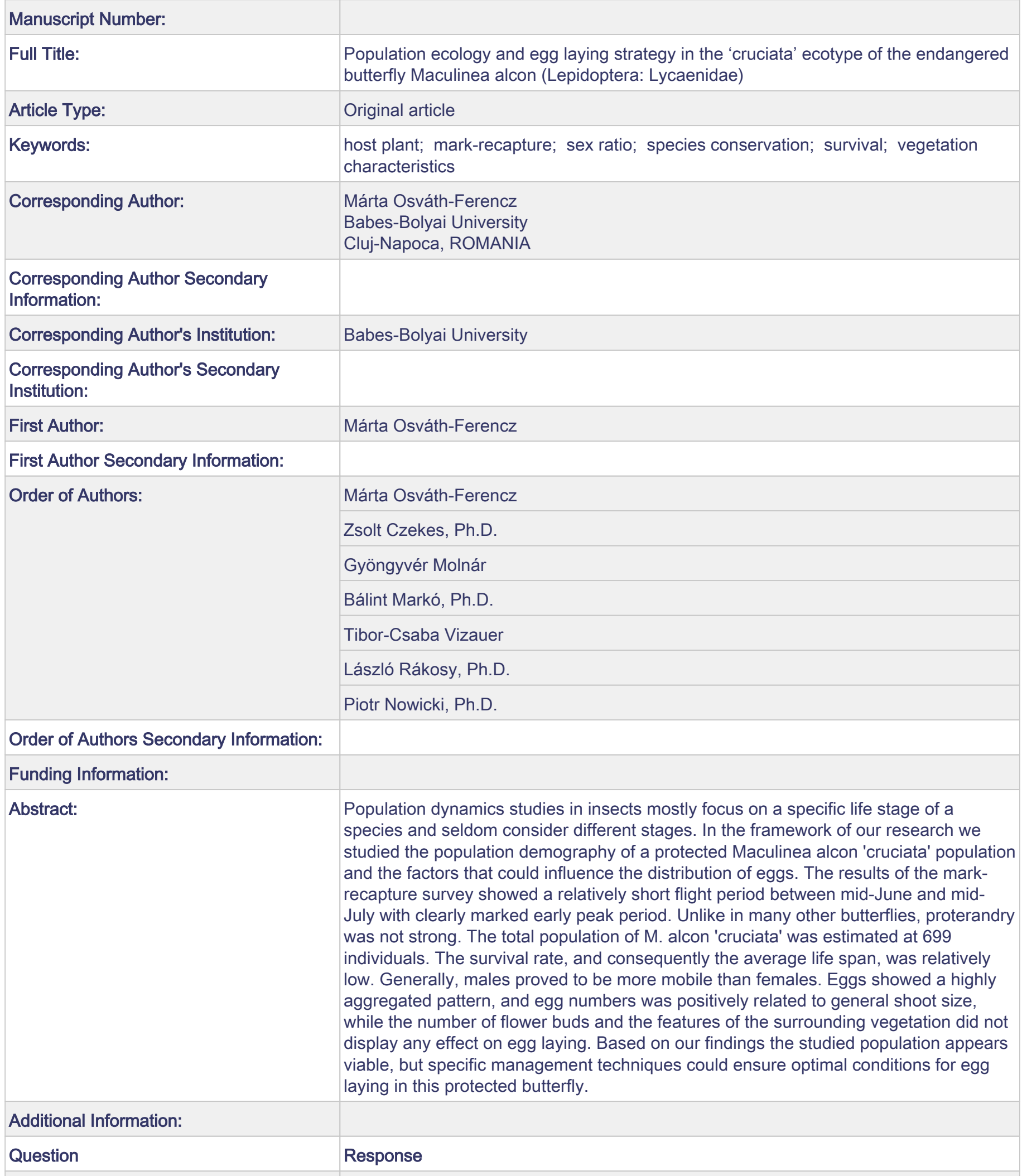


1 Title: Population ecology and egg laying strategy in the 'cruciata' ecotype of the

2 endangered butterfly Maculinea alcon (Lepidoptera: Lycaenidae)

3

4 Authors: Márta Osváth-Ferencz ${ }^{1 *}$, Zsolt Czekes ${ }^{1 *}$, Gyöngyvér Molnár ${ }^{1}$, Bálint

5 Markó $^{1,2}$, Tibor-Csaba Vizauer ${ }^{3}$, László Rákosy $^{4}$, Piotr Nowicki $^{5}$

6

7 Affiliations:

$8 \quad{ }^{1}$ Hungarian Department of Biology and Ecology, Babeș-Bolyai University, 400006

9 Cluj-Napoca, Clinicilor str. 5-7, Romania

$10{ }^{2}$ Department of Ecology, University of Szeged, Hungary

$11{ }^{3}$ Romanian Lepideptorological Society, Cluj-Napoca, Romania

$12{ }^{4}$ Department of Taxonomy and Ecology, Babeș-Bolyai University, 400006 Cluj-

13 Napoca, Clinicilor str. 5-7, Romania

$14{ }^{5}$ Institute of Environmental Sciences, Jagiellonian University, Kraków, Poland

15

$16 *$ contact authors and addresses:

17 Márta Osváth-Ferencz

18 Hungarian Department of Biology and Ecology, Babeș-Bolyai University, Cluj-

19 Napoca, Romania, ferenczke@ hotmail.com

20 Zsolt Czekes

21 Hungarian Department of Biology and Ecology, Babeș-Bolyai University, Cluj-

22 Napoca, Romania, czekes@gmail.com

23

24 No. of text pages: 17

25 No. of figures: 5 
26 No. of tables: 3

27

\section{Abstract}

29 Population dynamics studies in insects mostly focus on a specific life stage of a species

30 and seldom consider different stages. In the framework of our research we studied the

31 population demography of a protected Maculinea alcon 'cruciata' population and the

32 factors that could influence the distribution of eggs. The results of the mark-recapture

33 survey showed a relatively short flight period between mid-June and mid-July with

34 clearly marked early peak period. Unlike in many other butterflies, proterandry was not

35 strong. The total population of M. alcon 'cruciata' was estimated at 699 individuals.

36 The survival rate, and consequently the average life span, was relatively low. Generally,

37 males proved to be more mobile than females. Eggs showed a highly aggregated

38 pattern, and egg numbers was positively related to general shoot size, while the number

39 of flower buds and the features of the surrounding vegetation did not display any effect

40 on egg laying. Based on our findings the studied population appears viable, but specific

41 management techniques could ensure optimal conditions for egg laying in this protected

42 butterfly.

43

44 Key-words: host plant; mark-recapture; sex ratio; species conservation; survival;

45 vegetation characteristics 
Dynamics of insect populations, mostly in the case of pests, and more recently

49 also in protected species, has been the subject of wide range of studies (Hassell et al.

50 1991, Way and Heong 1994, Hunter 2001, Yamamura et al. 2006, Thomas et al. 2009).

51 Most of these studies though concentrate on a single life stage of an insect (e.g., adults,

52 larvae), while usually neglecting the parallel investigations into other developmental

53 stages, or the connection between them (Jones and Sullivan 1982, Elkinton and

54 Liebhold 1990, Yamamura et al. 2006, Ordano et al. 2015). Admittedly, it is much

55 easier, and therefore much more practical to determine the viability of any population

56 based solely on the abundance of adults, consequently many pest control and species

57 conservation actions primarily rely on such information (Jones and Sullivan 1982,

58 Katsoyannos 1992, Steytler and Samways 1995, Sunderland and Samu 2000, Thomas et

59 al. 2009, Vrezec et al. 2012). However, linking the dynamics of adults with e.g., egg

60 laying patterns can offer a more precise picture of the sustainability of certain

61 populations in a given area, since the viability of a population is primarily determined

62 by the number of offspring produced in the study area, i.e., in the case of insects by the

63 number of eggs and/or larvae (Begon et al. 1996). In winged insects, such as butterflies,

64 which disperse very efficiently, this combined information is vital, since the mere

65 presence of adults might not imply the persistence of a population in that area at all, it

66 could merely be a sign of efficient dispersal of adults.

67 The population dynamics of adult butterflies is frequently connected to weather 68 conditions and environmental stochasticity (Melbourne and Hastings 2008, Nowicki et 69 al. 2009, Cormont et al. 2013), while adult egg laying decisions, thus the fate of their 
70 offspring primarily relies on the condition of host plants, the strength of intraspecific

71 competition, predatory pressure or other habitat parameters (Stamp 1980, Wiklund

72 1984, Bergman 2001, Czekes et al. 2014). Ovipositing females have to choose the

73 optimal site for their offspring, as well as the best available host plant within the site.

74 Additionally, the survival of the offspring can also be affected by the host plants' direct

75 or indirect responses to the presence of eggs and/or larvae as well (see Hilker and

76 Fatouros 2015 for a review). In the present study we investigated the within-season

77 dynamics of adult butterflies in the 'cruciata' ecotype of the endangered Maculinea

78 alcon (featured in many former studies as Maculinea rebeli) while linking it to egg

79 laying patterns and preferences.

80

Large Blue butterflies of the genus Maculinea Van Eecke, 1915 (synonymised

81 lately with Phengaris Doherty, 1891) are one of the most intensively studied butterfly

82 groups in Europe, being considered flagship and umbrella species in nature

83 conservation. They are highly sensitive to habitat changes, and the conservation of their

84 habitats is beneficial to many other threatened species (Thomas et al. 1998a, Thomas

85 and Settele 2004, Nowicki et al. 2005a, Settele et al. 2005). In the past decades severe

86 declines were recorded in most of their Western European populations due to habitat

87 fragmentation and intensification of agriculture (Van Swaay and Warren 1999, Van

88 Swaay et al. 2010). They also raise specific scientific interest due to the intriguing

89 obligate myrmecophylic lifestyle of their larvae (see Witek et al. 2010). Most

90 Maculinea populations are small and isolated (Thomas et al. 1998b, Meyer-Hozak

91 2000), characterized by density dependent regulation due to intra-specific competition

92 between larvae on host plants and/or in host ant colonies (Hochberg et al. 1992,

93 Nowicki et al. 2009). Long-term surveys have already shown the importance of weather 
94 patterns (Roy et al. 2001, Cormont et al. 2013), but Maculinea populations are also

95 affected by general habitat characteristics (Nowicki et al. 2007), and human activities

96 (e.g., changes in agricultural practices) (Schmitt and Rákosy 2007).

Despite a relatively large number of both field and modelling studies into the

98 ecology of M. alcon 'cruciata' (e.g., Hochberg et al. 1992, Meyer-Hozak 2000, Árnyas

99 et al. 2006, Oskinis 2012, Timuș et al. 2013, Czekes et al. 2014), hardly any of them

100 investigated the adult population size and their egg laying behaviour at the same time

101 (Meyer-Hozak 2000, Körösi et al. 2008). Furthermore, none of these studies combined

102 the information from both sources in a joint analysis. Despite the need for complex

103 information on populations of protected butterflies, such studies are generally rare in

104 case of other butterfly species as well (see Bergman 2001). Consequently, the aims of

105 our research were to (a) study the within-season dynamics of a M. alcon 'cruciata'

106 population, while also (b) examining the temporal changes in the deposition of eggs,

107 and (c) identifying the factors influencing the distribution of eggs.

108

109 Materials and methods

110

111 Study species and site

112 Two major ecotypes of the butterfly M. alcon are differentiated based on their

113 host plant: the hygrophilous form feeding on Gentiana pneumonanthe (previously

114 treated as M. alcon), and the more xerophilous form feeding on G. cruciata (previously

115 treated as $M$. rebeli, hereafter referred to as M. alcon 'cruciata'). Recent molecular

116 studies showed that the two forms cannot be regarded as different species (Als et al.

117 2004, Bereczki et al. 2005, Steiner et al. 2006, Pecsenye et al. 2007). Nevertheless, in

118 addition to habitat and host plant segregation, they typically use different host ant 
119 species, and they also have different flight periods (Bereczki et al. 2005, Pech et al. 120 2004, Sielezniew et al. 2012). M. alcon 'cruciata' prefers semi-natural calcareous

121 grasslands (Bálint 1994, Pech et al. 2004, Rákosy and Vodă 2008), and it uses quite a

122 wide range of host ant species from the genus Myrmica Latreille, 1804, which adopt

123 them due to their efficient chemical and acoustical mimicry (see Fiedler 2006 and Witek

124 et al. 2014 for a review). Their development continues inside the ant nest, where they

125 are fed by the ant workers (Elmes et al. 1991). The flight period of adult butterflies is

126 from mid-June to mid-July (Meyer-Hozak 2000, Körösi et al. 2008, Timuș et al. 2013).

127 The conservation status of M. alcon is Least Concern according to the IUCN Red List in

128 Europe and Near Threatened in the European Union (Van Swaay et al. 2010).

129 The field study was performed on a $9252 \mathrm{~m}^{2}$ semi-natural calcareous dry

130 grassland of southeastern exposure in the surroundings of Rimetea village

131 (N46²7'51.45”, E23³3'46.26”, ca. $620 \mathrm{~m}$ a.s.1., Romania). The grassland is a plant

132 species-rich meadow dominated by Brachypodium pinnatum, Carex humilis and

133 Festuca rupicola with other characteristic species like Dorycnium pentaphyllum,

134 Cytisus albus, Hieracium bauhinii, Teucrium montanum and Thymus serpyllum, and it

135 is intensively grazed by goats and sheep. The meadow is partially surrounded by a

136 mixed forest and shrubs of Crataegus monogyna, Prunus spinosa, Pyrus pyraster and

137 Rosa canina. The site constitutes a part of the ROSCI0253 'Trascău' Natura 2000

138 protected site.

139

140 Data collection

141 a) Population dynamics survey 
143 between 15 June and 16 July 2012 covering the entire flight period. The survey plan

144 followed the requirements of the Pollock's Robust Design approach (Pollock 1982;

145 Pollock et al. 1990), i.e. relatively infrequent but highly intensive capture days were

146 established, which constituted primary sampling periods. The sampling took place on

147 every fourth day, with a single exceptional case in which the interval between

148 consecutive capture days was reduced to three days due to the forecast of unfavourable

149 weather conditions on the following days. Butterflies were surveyed between 10 AM

150 and 5 PM during five one-hour capture sessions, regarded as secondary sampling

151 periods, and were separated by 30 min breaks to allow free mixing of butterflies

152 between the secondary sampling periods. Captured individuals were marked on the

153 underside of their hind-wing with unique identity numbers using a fine-tipped

154 waterproof pen (ㅇ Schneider $\mathrm{GmbH}$ ), and then immediately released at the place of

155 capture. For each capture we recorded the date, the exact time and the position of each

156 capture (GPS coordinates), as well as the identity number and the sex of the adult.

158 b) Distribution of butterfly eggs

159 Prior to the adult butterfly survey we randomly placed out 22 sampling plots

160 within the study site. The plots were circles of $2 \mathrm{~m}$ radius, as generally applied in the

161 case of Maculinea species based on the average foraging radius of the host ant Myrmica

162 (see Elmes 1975, Elmes et al. 1998), with a focal G. cruciata plant in the middle.

163 Within the plots we recorded the number of all G. cruciata host plants, and the number

164 of their shoots. Shoots were considered to belong to the same plant when they were

165 obviously connected either above the soil surface. In order to minimise disturbance, we 
166 recorded the number of eggs on the focal host plant within each plot $(n=22)$ only at the

167 end of each mark-recapture sampling day. At the end of the whole study period we

168 counted all eggs found on all host plant shoots within the sampling plots in addition to

169 the characteristics of the host plants and general vegetation features. The following

170 parameters were recorded: (a) the total number of butterfly eggs laid on the host plant

171 shoots, and separately on different verticils, (b) shoot height as the length of the shoot

$172(\mathrm{~cm}),(\mathrm{c})$ number of shoot leaves, and (d) number of flowers (only flower buds with

173 coloured sepals were taken into account since small green flower buds are impossible to

174 count sometimes) on separate verticils of shoots, (e) the number of host plants in each

175 plot, (f) the maximum height of the surrounding vegetation $(\mathrm{cm})$, and $(\mathrm{g})$ the proportion

176 of vegetation cover visually estimated to the nearest $5 \%$.

177

178 Data analysis

179 Mark-recapture data was analysed with the use of Mark 7.0 program (White and

180 Burnham 1999) applying the Robust Design (RD) model (Pollock 1982; Kendall et al.

181 1995). The RD model allows relatively high precision of population estimates, and it

182 has proved its applicability in butterfly population studies (Nowicki et al. 2008). The

183 analyses were conducted separately for males and females, because sex-specific

184 population parameters were of interest for our study. The data from capture sessions

185 (i.e. secondary periods of the RD model) within sampling days were used to estimate

186 daily population sizes for these days $\left(N_{i}\right)$. In the estimation we accounted for individual

187 heterogeneity in capture probabilities, since its existence was revealed by the tests for

188 violations to equal catchability assumption (Otis et al. 1978; Chao 1988). In turn, the

189 data pooled together within capture days (i.e. primary periods of the RD model) were 
190 used for assessing survival rate between these days $\left(\varphi_{i}\right)$. The model variant assuming no 191 time variation in survival rate performed the best as indicated by its lowest value of the

192 Akaike Information Criterion corrected for small sample (AIC $\mathrm{A}_{\mathrm{c}}$; Hurvich and Tsai 193 1989), which implies that adult survivorship was fairly constant throughout the flight

194 period. Subsequently, we calculated the average adult lifespan as $e=(1-\varphi)^{-1}-0.5$ 195 (Nowicki et al. 2005b). Based on the estimates of daily population sizes and survival rates, we also 197 estimated the recruitment $\left(B_{i}\right)$, i.e. the numbers of individuals eclosing from pupae and 198 entering the adult population during the intervals between consecutive capture days. As 199 the adult life span was relatively short when compared with the length of these intervals $200\left(d_{i}\right)$, we used the formula of Nowicki et al. (2005a; see this reference for the rationale), 201 which accounts for the individuals eclosing and dying within the same intervals: $B_{i}{ }^{\prime}=d$ $202 \times\left(N_{i+1}-N_{i} \cdot \varphi^{d}\right) \times(\varphi-1) /\left(\varphi^{d}-1\right)$. The sum of recruitment for the entire flight period 203 makes up seasonal population size $\left(N_{\text {total }}\right)$. In a similar way, by summing female 204 recruitments prior to each capture day, we derived the total numbers of females present 205 until these days.

206 To compare the distances covered by female and male butterflies we measured 207 the distance between the two furthermost points where an individual was captured. We 208 also measured the area of the polygon marked by the capture points of an individual in 209 order to compare the area covered by female and male butterflies. The measurements 210 were based on recorded GPS coordinates and conducted using Garmin Mapsource 211 software (version 6.16.3, Garmin Ltd. 1999-2010). The flight distances and areas could 212 be quantified only in the case of individuals which were captured at least twice (for 213 distance), and three times (for area), therefore, due to the low recapture rate, a relatively 
214 small data set was available for analysis $(n=11$ females and 59 males for distance; $n=5$

215 females and 28 males for area). Wilcoxon signed rank test were used for the comparison

216 of flight distances between males and females. Due to the low sample size a similar

217 analysis was not performed for the area covered.

218 Poulin's discrepancy index (Rózsa et al. 2000) was used to characterize the

219 distribution of eggs on all host plants within sampling plots recorded at the end of the

220 study period. Biases in the distribution of eggs among different host plant verticils were

221 checked with Generalized Linear Mixed Model approach (GLMM, Poisson error,

222 maximum likelihood approximation; $\mathrm{n}=133$ ). The number of eggs laid on different

223 verticils of egg bearing plant shoots was introduced as dependent variable, while the ID

224 of verticil as independent factor. Sampling plot and plant IDs were introduced as nested

225 random factors to handle dependency of data. Only egg data regarding the top four

226 verticils were taken into account since no eggs were recorded on lower verticils.

227 We tested the relationship between the estimated number of females present

228 before each sampling day, and the total number of eggs laid in the same period $(n=8)$

229 in order to reveal whether the number of eggs laid is related to the number of female

230 butterflies. Spearman rank correlation analysis was applied due to the lack of normality

231 of both variables. In addition, the effect of the abundance of eggs already present on

232 oviposition was checked by testing the relationship between the number of eggs present

233 and the number of newly laid eggs in the following period for seven consecutive periods

234 between the eight sampling days. Again, Spearman rank correlation analysis was

235 applied in this case. 
238 analyzed with the use of GLMM approach (Poisson error, maximum likelihood

239 approximation; $\mathrm{n}=410$ ). Correlation between host plant characteristics were checked

240 using Spearman rank correlation analysis due to non-normality of datasets. A principal

241 component analysis (PCA) was applied to obtained uncorrelated derived variables for

242 plant characteristics, and the principal components were used as independent variables

243 in the GLMM analysis. The number of eggs laid on each focal host plant was

244 introduced as a dependent variable, while independent variables were the host plant

245 morphological characteristics (PC1 [correlated plant height and number of leaves] and

246 PC2 [correlated number of flower buds]), the number of host plants in sample plots, the

247 maximum height of the surrounding vegetation, and vegetation cover. Sampling plot

248 and host plant IDs were introduced as random factors to handle dependencies.

249 Automated model selection procedure was carried out, and the effects of different

250 explanatory variables were averaged across the supported models with delta $\mathrm{AIC}_{\mathrm{c}}<4$,

251 i.e. those with the $\mathrm{AIC}_{\mathrm{c}}$ differing by less than 4 from the best model (see Grueber et al., 252 2011).

253 All statistical analyses were carried out using the R 3.1.1 Statistical Environment

254 (R Development Core Team 2014) and Quantitative Parasitology 3.0 (Rózsa et al.,

255 2000). Normality of datasets was regularly checked with the Shapiro-Wilk test. Relevel

256 function was used in order to carry out post-hoc sequential comparisons among factor

257 levels when performing GLMM. GLMMs were carried out with the use of glmer

258 function in lme4 package (Bates et al. 2014), and dredge function in MuMIn package

259 (Barton 2015) was applied for automated model selection. Table-wide Bonferroni-Holm

260 correction was applied in the case of sequential comparisons, such as Spearman rank 
correlations and comparison of factor levels in the GLMM analysis concerning the

262 location of eggs on different verticils.

263

264 Results

265

266 Demography of adult butterflies

During the entire study we captured and marked $152(67.5 \%)$ males and 73

268 (32.5\%) females, out of which 85 males and 14 females, respectively, were recaptured

269 at least once. The total adult population was assessed at 699 individuals, with a

270 relatively balanced sex ratio (55\% males vs. $45 \%$ females) (Table 1$)$. The estimated

271 survival was fairly low, which translates in rather short adult lifespan of ca. 2 days with

272 no major inter-sexual difference (Table 1).

273 The butterfly had a relatively short flight period between mid-June and mid-

274 July, with a clearly pronounced peak occurrence in the early part of the period (Fig. 1).

275 More than $50 \%$ of individuals emerged within the first week, and more than $80 \%$ within

276 the first two weeks (Fig. 1). Besides, in comparison to many other species of butterfly,

277 we found rather weak proterandry (cf. Pfeifer et al. 2000; Nowicki et al. 2005b): the

278 number of females peaked only three days after the peak of males.

279 Most of the butterflies clearly preferred the close proximity of shrubs (Fig. 2).

280 The mean distance covered by males was $81.61 \mathrm{~m}(\mathrm{SD}= \pm 56.99, \min =9, \max =217)$,

281 and the mean area was $1766.98 \mathrm{~m}^{2}(\mathrm{SD}= \pm 2260.67, \min =25, \max =8091)$. Females

282 were less mobile, with a mean flight distance of $53.9 \mathrm{~m}(\mathrm{SD}= \pm 57.72, \min =14, \max =$

283 213), and with a mean area of $193 \mathrm{~m}^{2}(\mathrm{SD}= \pm 289.19, \min =5, \max =684)$. Males

284 covered significantly longer distances, than females (Wilcoxon signed rank test $\mathrm{W}=$ $285454, \mathrm{p}<0.05)$. 
287 Egg laying dynamics and preferences

At the end of the study altogether 94 eggs were recorded on a total of $410 \mathrm{G}$.

289 cruciata shoots of 201 plants within the 22 study plots. More than $90 \%$ of the shoots

290 lacked eggs, and the maximum number of eggs was 23 on a single shoot. The overall

291 mean egg density was 0.47 eggs/plant, and 0.23 eggs/shoot (4.48 eggs/plant and 4.09

292 eggs/shoot only for plants with eggs); while the mean host plant density was 0.72

293 plants $/ \mathrm{m}^{2}$ (9.05 plants/plot), and 1.48 shoots $/ \mathrm{m}^{2}$ (18.6 shoots/plot). The distribution of

294 eggs on plants showed a highly aggregated pattern (Fig. 3) as indicated by Poulin's

295 discrepancy index $(\mathrm{D}=0.97)$. Eggs were laid only on the top four verticils of the plants.

296 Most eggs were laid on the $2^{\text {nd }}$ verticil (33.93\% of total), but no significant differences

297 were revealed between the number of eggs on the different verticils (GLMM, $\mathrm{z} \leq 1.487$, $298 \mathrm{p}=\mathrm{NS}, \mathrm{n}=133)$.

299 Eggs were recorded even during the first part of the study period on the focal

300 host plants of the sampling plots $(n=22)$, even if less than $10 \%$ of the focal plants bore

301 eggs on the $2^{\text {nd }}$ sampling day (22.06). By the $6^{\text {th }}$ sampling day (08.07) $63 \%$ of the plants

302 had eggs, after this the percentage of egg bearing plants decreased (Fig 4.). The number

303 of eggs laid before each capture period did not correlate with the number of females

304 recruited in the same period (Spearman $r=0.53, p=0.13, n=8$ ). In turn, the number of

305 newly laid eggs correlated negatively with the number of eggs already present on host

306 plants, the negative correlations between the two variables reached statistical

307 significance level during all but two sampling periods (Table 2).

308 Host plant morphological characteristics were mostly correlated according to the 309 results of the Spearman rank-correlation analysis $(n=410)$ : height vs. number of leaves 
$310 \mathrm{r}=0.5, \mathrm{p}<0.001 ;$ number of leaves vs. number of flower buds $\mathrm{r}=0.25, \mathrm{p}<0.001$;

311 height vs. number of flower buds $r=0.10, p=0.050$. The PCA yielded $1^{\text {st }}(P C 1)$ and $2^{\text {nd }}$

312 (PC2) principal components that explained $52 \%$ and $31 \%$ of the variance, respectively.

313 PC1 represented plant height and number of leaves with loadings of 0.66 and 0.68 ,

314 respectively, as a measure of general shoot size, while PC2 reflected the number of

315 flower buds with a loading of 0.94. All input variables were retained in the best average

316 GLMM model for egg laying preferences (Table 3), but only the general shoot size

317 (PC1) had a significant positive effect on the number of eggs laid $(\mathrm{z}=4.59, \mathrm{p}<0.001$;

318 Fig. 5), while none of the other variables displayed any significant effects $(\mathrm{z} \leq 1.63, \mathrm{p}=$ 319 NS)

321 Discussion

The results of the present study show that the studied butterfly population

324 appears fairly viable based on the comparison with other studies concerning the size of

325 M. alcon 'cruciata' populations (Árnyas et al. 2005, Timuș et al. 2013). During a three

326 year long MRR study Árnyas et al. (2005) found that on a 0.75 ha site the studied $M$.

327 alcon 'cruciata' population was stable with nearly 1000 individuals, while Timuș et al.

328 (2013) estimated the size of another population in Romania to 1073 individuals for a 40

329 ha site. In comparison, the size of our studied population (699 individuals on $\sim 1$ ha)

330 suggests that the population is relatively big. Generally, Maculinea alcon populations

331 show very small fluctuations (Hochberg et al. 1994, Elmes et al. 1996), thus there is a

332 considerable chance that our studied population is stable.

333 Similarly to other studies (Meyer-Hozak 2000, Árnyas et al. 2005), we found

334 that the butterflies fly from mid-June to mid-July. In some cases the flight period takes 
335 less than one month (Timuș et al. 2013), which can reflect differences in habitat or/and 336 meteorological conditions of different populations. Although we found a relatively

337 weak indication of proterandry, the peak emergence of males still preceded that of

338 females. This phenomenon is in fact common for all Maculinea species and for

339 butterflies in general. According to Elmes and Thomas (1987) the males pupate a few

340 days before females, and thus during the initial part of the flight period the population is

341 dominated by males. During the entire study we caught roughly twice as many male

342 individuals as female, but the estimated sex ratio was relatively balanced, which

343 corresponds with results of other studies (Árnyas et al. 2005, Timuș et al. 2013).

344 Considerably higher capture and recapture rates of males may be attributed also to the

345 fact that they fly more often and higher searching for the less mobile females. The latter

346 tend to fly lower because they are searching for food plants in the undergrowth (Árnyas 347 et al. 2005).

348 Earlier mark-recapture and individual tracking studies suggested that Maculinea 349 butterflies are highly sedentary (Hovestadt and Nowicki 2008, Körösi et al. 2008, 350 Hovestadt el al. 2011, Skórka et al. 2013). Our results concerning adult mobility also 351 support this fact. Keeping close to the place of eclosion can be an adaptation of these 352 butterflies to myrmecophily (Hovestadt and Nowicki 2008). Inter-sexual differences 353 were revealed by our study: males proved to be more mobile than females. On the other 354 hand, similar research on other Maculinea species showed higher mobility in females 355 (Körösi et al. 2012, Skórka et al. 2013), which could be attributed to females trying to 356 decrease intra-specific competitive pressure among their offsprings (Nowicki and 357 Vrabec 2011). However, all these studies were carried out on M. teleius and M. 358 nausithous, i.e. species with more restricted habitat requirements (wet meadows) and 
359 higher population densities in comparison to M. alcon 'cruciata', which prefers semi-

360 dry grasslands and has lower population densities (Meyer-Hozak 2000, Nowicki et al.

361 2007). In our population the higher mobility of males is likely to stem from the high

362 male/female ratio due to which males may need to cover larger areas in order to find

363 mating partners. Therefore, male mobility may play a crucial role in gene flow in our

364 population (Piaggio et al. 2009, Solmsen et al. 2011).

Phytophagous butterfly species mostly lay their eggs separately one by one or in

366 clusters (Stamp 1980 for a review, Vulinec 1990, Dixon and Guo 1993). Both strategies

367 can influence positively the survival of eggs and larvae. Females can lower the chances

368 of predation and competition for their offspring by depositing their eggs individually. In

369 these cases eggs are usually cryptic (light yellow or green) and are laid on protected

370 parts of the host plants (see Stamp 1980). Laying eggs in clusters can be advantageous

371 when other factors can affect negatively the reproduction, like the patchy distribution of

372 host plants, the scarcity of resources for larvae and adults, low population density or

373 unfavorable weather conditions (Stamp 1980, Karlsson and Johansson 2008,. Karlsson

374 et al. 2008). Besides, as clusters of eggs and larvae are more protected from desiccation

375 when clumped together, clusters can ensure higher survivability through lower

376 sensitivity to ambient conditions (Stamp 1980, Clark and Faeth 1998). During our study

377 we found a low mean egg density per host plants (0.47 eggs/plant) compared to that

378 recorded by Czekes et al. (2014) in another population (8.89 eggs/plant). In addition, the

379 distribution of eggs among host plants showed a clearly aggregated pattern, thus most of

380 the eggs were concentrated only on a few host plants. This could suggest the patchy

381 distribution of host ants, however there is no convincing evidence yet that ovipositing 
401 for oviposition. A visually conspicuous host plant (i.e. tall ones with many leaves) may

402 be more attractive or more perceptible for females than smaller ones (Nowicki et al.

403 2005a, Van Dyck and Regniers 2010, Czekes et al. 2014, Arnaldo et al. 2014, Wynhoff

404 et al. 2015). The large number of eggs on tall plants with a high number of leaves can

405 be beneficial for the butterflies due to an increased egg laying surface, decreased larval 
406 competition, or even better climatic conditions. Wynhoff et al. (2015) suggested that

407 larger host plants might provide high quantities of food for the caterpillars because of

408 bearing later many fully developed flower buds. Maculinea alcon 'cruciata' females

409 laid their eggs exclusively on the four top verticils of their host plants, which could be

410 attractive sites for oviposition presumably also because of the lower predation risk for

411 adult females (Van Dyck and Regniers 2010) and the better microclimate for larval

412 development (Alonso 2003). In addition, ovipositing mostly on the $2^{\text {nd }}$ verticil from the

413 top, as suggested by our results, could ensure better climatic conditions to eggs through

414 reduced exposure to sun and wind.

415 Linking population demography data to oviposition preferences could help the

416 protection of the focal butterfly species not only by offering data to nature

417 conservationists, but also by revealing that specific management techniques could

418 ensure better conditions for egg laying. Specifically, sustaining a low grazing pressure

419 could have a positive effect on the butterfly population (WallisDeVries and Raemakers

420 2001), and it would also keep shrubs from invading the grassland.

422 Acknowledgements

424 We thank Annamária Fenesi and Krisztina Havadtöi for the characterization of the study

425 area's vegetation, Ádám Körösi for his helpful comments on the manuscript, and Paul

426 Kirkland for linguistic corrections which contributed to the improvement of the

427 manuscript. M.O-F.'s work was supported by the Sectoral Operational Programme for

428 Human Resources Development 2007-2013, co-financed by the European Social Fund,

429 under the project POSDRU/159/1.5/S/133391: "Doctoral and postdoctoral excellence

430 programs for training highly qualified human resources for research in the fields of Life 
431 Sciences, Environment and Earth". Furthermore the study was funded by the Polish

432 National Science Centre grant DEC-2013/11/B/NZ8/00912. During preparation of the

433 manuscript Zs.C.'s work was supported by a grant of the Ministry of National

434 Education (Romania), CNCS-UEFISCDI, project no. PN-II-ID-PCE-2012-4-0595,

435 while B.M.'s work was helped by the Bolyai János Scholarship of the Hungarian

436 Academy of Sciences. 


\section{References}

438 Als TD, Vila R, Kandul NP, Nash DR, Yen SH, Hsu YF, Mignault AA, Boomsma JJ,

439 Pierce NE (2004) The evolution of alternative parasitic life histories in Large Blue

440 butterflies. Nature 432:386-390. DOI 10.1038/nature03020

441 Arnaldo PS, Gonzalez D, Oliveira I, Van Langevelde F, Wynhoff I (2014) Influence of

442 host plant phenology and oviposition date on the oviposition pattern and offspring

443 performance of the butterfly Phengaris alcon. J Insect Conserv 18:1115-1122. DOI

444 10.1007/s10841-014-9721-x

445 Árnyas E, Bereczki J, Tóth A, Pecsenye K, Varga Z (2006) Egg-laying preferences of

446 the xerophilous ecotype of Maculinea alcon (Lepidoptera: Lycaenidae) in the Aggtelek

447 National Park. Eur J Entomol 103:587-595. DOI 10.14411/eje.2006.079

448 Árnyas E, Bereczki J, Tóth A, Varga Z (2005) Results of the mark-release-recapture

449 studies of a Maculinea rebeli population in the Aggtelek karst (N Hungary) between

450 2002-2004. In: Settele J, Kühn E, Thomas J (eds) Studies on the Ecology and

451 Conservation of Butterflies in Europe. Vol. 2. Species ecology along a European

452 Gradient: Maculinea butterflies as a model. Pensoft Publishers, Sofia-Moscow, pp. 111-

$453 \quad 114$

454 Árnyas E, Bereczki J, Tóth A, Varga K, Pecsenye K, Tartally A, Kövics Gy, Karsa D,

455 Varga Z (2009) Oviposition preferences of Maculinea alcon as influenced by aphid

456 (Aphis gentianae) and fungal (Puccinia gentianae) infestation of larval host plants. Ecol

457 Entomol 34:90-97. DOI 10.1111/j.1365-2311.2008.01048.x

458 Barton K (2014) MuMIn: Multi-model inference. R package version 1.10.5.

459 http://CRAN.R-project.org/package=MuMIn. 
460 Bates D, Mächler M, Bolker B, Walker S (2014) Fitting Linear Mixed-Effects Models

461 using lme4. J Stat Softw 51. DOI http://arxiv.org/abs/1406.5823

462 Bálint Zs (1994) Magyarország nappali lepkéi a természetvédelem tükrében

463 (Lepidoptera, Rophalocera). Somogyi Múzeumok Közleményei, 10:183-206

464 Begon M, Mortimer M, Thompson DJ (1996) Population Ecology: A Unified Study of

465 Animals and Plants. Blackwell Science, USA. DOI 10.1002/9781444313765.fmatter

466 Bereczki J, Pecsenye K, Peregovits L, Varga Z (2005) Pattern of genetic differentiation

467 in the Maculinea alcon species group (Lepidoptera, Lycaenidae) in Central Europe. JZS

468 43:157-165. DOI 10.1111/j.1439-0469.2005.00305.157-165

469 Bergman K-O (2001) Population dynamics and the importance of habitat management

470 for conservation of the butterfly Lopinga achine. J Appl Ecol 38:1303-1313.

471 DOI 10.1046/j.0021-8901.2001.00672.x

472 Chao A (1988) Estimating animal abundance with capture frequency data. J Wildl

473 Manage 52:295-300. DOI 10.2307/3801237

474 Clark BR, Faeth SH (1998) The evolution of egg clustering in butterflies: A test of the

475 egg desiccation hypothesis. Evol Ecol 12:543-552. DOI 10.1023/A:1006504725592

476 Cormont A, Wieger Wamelinka GW, Jochema R, WallisDeVries MF, Wegmana RMA

477 (2013) Host plant-mediated effects of climate change on the occurrence of the Alcon

478 blue butterfly (Phengaris alcon). Ecol Model 250:329-337. DOI

479 10.1016/j.ecolmodel.2012.11.022

480 Czekes Zs, Markó B, Nash DR, Ferencz M, Lázár B, Rákosy L (2014) Differences in

481 oviposition strategies between two ecotypes of the endangered myrmecophilous

482 butterfly Maculinea alcon (Lepidoptera: Lycaenidae) under unique syntopic conditions.

483 Insect Conserv Divers 7:122-131. DOI 10.1111/icad.12041 
484 Dixon AFG, Guo Y (1993) Egg and cluster size in ladybird beetles (Coleoptera:

485 Coccinellidae): The direct and indirect effects of aphid abundance. Eur J Entomol $48690: 457-463$.

487 Dolek M, Geyer A, Bolz R (1998) Distribution of Maculinea 'rebeli' and hostplant use 488 on sites along the river Danube. J Insect Conserv 2:85-89. DOI

489 10.1023/A:1009601024873

490 Elkinton JS, Liebhold AM (1990) Population Dynamics of Gypsy Moth in North

491 America. Annu Rev Entomol 35:571-596. DOI 10.1146/annurev.en.35.010190.003035

492 Elmes GW (1975) Population Studies on the Genus Myrmica (Hymenoptera,

493 Formicidae), with Special Reference to Southern England. University of London,

494 London

495 Elmes GW, Clarke RT, Thomas JA, Hochberg ME (1996) Empirical tests of specific

496 predictions made from a spatial model of the population dynamics of Maculinea rebeli,

497 a parasitic butterfly of red ant colonies. Acta Oecol 17:61-80.

498 Elmes GW, Thomas JA (1987) Die Gattung Maculinea. In Geiger W (eds) Tagfalter

499 und ihre Lebensraeume: Arten, Gefaehrdung, Schutz. Schweizerische Bund für

500 Naturschutz. Basel, pp 354-368

501 Elmes GW, Thomas JA, Wardlaw JC, Hochberg ME, Clarkel RT, Simcox DJ (1998)

502 The ecology of Myrmica ants in relation to the conservation of Maculinea butterflies. J

503 Insect Cons 2:67-78. DOI 10.1023/A:1009696823965

504 Elmes GW, Wardlaw JC, Thomas JA (1991) Larvae of Maculinea rebeli, a large blue

505 butterfly, and their Myrmica host ants: patterns of caterpillar growth and survival. J

506 Zool 224:79-92. DOI 10.1111/j.1469-7998.1991.tb04789.x 
507 Fiedler K (2006) Ant-associates of Palaearctic lycaenid butterfly larvae (Hymenoptera:

508 Formicidae; Lepidoptera: Lycaenidae) - a review. Myrmecol Nachr 9:77-87

509 Fürst MA, Nash DR (2010) Host ant independent oviposition in the parasitic butterfly

510 Maculinea alcon. Biol Lett 6:174-176. DOI 10.1098/rsbl.2009.0730

511 Hassel MP, Comins HN, May RM (1991) Spatial structure and chaos in insect

512 population dynamics. Nature 353:255-258. DOI 10.1038/353255a0

513 Grueber CE, Nakagawa S, Laws RJ, Jamieson IG (2011) Multimodel inference in

514 ecology and evolution: challenges and solutions. J Evol Biol 24:699-711.

515 Hilker M, Fatouros NE (2015) Plant Responses to Insect Egg Deposition. Annu Rev

516 Entomol 60:493-515. DOI 10.1146/annurev-ento-010814-020620

517 Hochberg ME, Clarke RT, Elmes GW, Thomas JA (1994) Population dynamic

518 consequences of direct and indirect interactions involving a large blue butterfly and its

519 plant and red ant hosts. J Anim Ecol 63:375-391. DOI 10.2307/5555

520 Hochberg ME, Thomas JA, Elmes GW (1992) A Modelling Study of the Population

521 Dynamics of a Large Blue Butterfly, Maculinea rebeli, a Parasite of Red Ant Nests. J

522 Anim Ecol 61:397-409. DOI 10.2307/5331

523 Hovestadt T, Binzenhöfer B, Nowicki P, Settele J (2011) Do all inter-patch movements

524 represent dispersal? A mixed kernel study of butterfly mobility in fragmented

525 landscapes. J Anim Ecol 80:1070-1077. DOI 10.1111/j.1365-2656.2011.01848.x

526 Hovestadt T, Nowicki P (2008) Investigating movement within irregularly shaped

527 patches: Analysis of mark-release-recapture data using randomization procedures. Isr J

528 Ecol Evol 54:137-154 
529 Hunter MD (2001) Insect population dynamics meets ecosystem ecology: effects of

530 herbivory on soil nutrient dynamics. Agric For Entomol 3:77-84. DOI 10.1046/j.1461-

$5319563.2001 .00100 . x$

532 Hurvich CM, Tsai C (1989) Regression and time series model selection in small

533 samples. Biometrika 76:297-307. DOI 10.1093/biomet/76.2.297

534 Jones WA, Sullivan MJ (1982) Role of Host Plants in Population Dynamics of Stink

535 Bug Pests of Soybean in South Carolina. Environ Entomol 11:867-875. DOI

$536 \quad 10.1093 / \mathrm{ee} / 11.4 .867$

537 Karlsson B, Johansson A (2008) Seasonal polyphenism and developmental trade-offs

538 between flight ability and egg laying in a pierid butterfly. Proc R Soc B 275:2131-2136.

539 DOI 10.1098/rspb.2008.0404

540 Karlsson B, Stjernholm F, Wiklund C (2008) Test of a developmental trade-off in a

541 polyphenic butterfly: direct development favours reproductive output. Funct Ecol

542 22:121-126. DOI 10.1111/j.1365-2435.2007.01334.x

543 Katsoyannos P (1992) Olive pests and their control in the Near East. FAO, Rome

544 Kendall WL, Pollock KH, Brownie C (1995) A likelihood-based approach to capture-

545 recapture estimation of demographic parameter under the robust design. Biometrics

546 51:293-308. DOI http://www.jstor.org/stable/2533335

547 Körösi Á, Örvössy N, Batáry P, Harnos N, Peregovits L (2012) Different habitat

548 selection by two sympatric Maculinea butterflies at small spatial scale. Insect Conserv

549 Divers 5:118-126. DOI 10.1111/j.1752-4598.2011.00138.x

550 Körösi Á, Örvössy N, Batáry P, Kövér S, Peregovits L (2008) Restricted within habitat

551 movement and time-constrained egg laying of female Maculinea rebeli butterflies.

552 Oecologia 156:455-464. DOI 10.1007/s00442-008-0986-1 
553 Melbourne BA, Hastings A (2008) Extinction risk depends strongly on factors

554 contributing to stochasticity. Nature 454:100-103. DOI 10.1038/nature06922

555 Meyer-Hozak C (2000) Population biology of Maculinea rebeli (Lepidoptera:

556 Lycaenidae) on the chalk grasslands of Eastern Westphalia (Germany) and implications

557 for conservation. J Insect Cons 4:63-72. DOI 10.1023/A:1009695031802

558 Nowicki P, Bonelli S, Barbero F, Balletto E (2009) Relative importance of density-

559 dependent regulation and environmental stochasticity for butterfly population dynamics.

560 Oecologia 161:227-239. DOI 10.1007/s00442-009-1373-2

561 Nowicki P, Pepkowska A, Kudlek J, Skórka P, Witek M, Settele J, Woyciechowski M

562 (2007) From metapopulation theory to conservation recommendations: Lessons from

563 spatial occurence and abundence patterns of Maculinea butterflies. Biol Conserv

564 140:119-129. DOI 10.1016/j.biocon.2007.08.001

565 Nowicki P, Richter A, Glinka U, Holzschuh A, Toelke U, Henle K, Woyciechowski M,

566 Settele J (2005a) Less input same output - simplified approach for population size

567 assessment in Lepidoptera. Popul Ecol 47:203-212. DOI 10.1007/s10144-005-0223-2

568 Nowicki P, Settele J, Henry P-Y, Woyciechowski M (2008) Butterfly monitoring

569 methods: the ideal and the real world. Isr J Ecol Evol 54:69-88. DOI

570 10.1560/IJEE.54.1.69

571 Nowicki P, Vrabec V (2011) Evidence for positive density-dependent emigration in

572 butterfly metapopulations. Oecologica 167:657-665. DOI 10.1007/s00442-011-2025-x

573 Nowicki P, Witek M, Skórka P, Settele J, Woyciechowski M (2005b) Population

574 ecology of the endangered butterflies Maculinea teleius and M. nausithous, and its

575 implications for conservation. Popul Ecol 47:193-202. DOI 10.1007/s10144-005-0222-

5763 
577 Ordano M, Engelhard I, Rempoulakis P, Nemny-Lavy E, Blum M, Yasin S, Lensky IM,

578 Papadopoulos NT (2015) Fruit Fly (Bactrocera oleae) Population Dynamics in the

579 Eastern Mediterranean: Influence of Exogenous Uncertainty on a Monophagous

580 Frugivorous Insect. PLoS ONE 10(5): e0127798. DOI 10.1371/journal.pone.0127798

581 Oškinis V (2012) Relationship between the butterfly Phengaris rebeli and its larval host

582 plant Gentiana cruciata in Lithuanian population. Ekologija 58:369-373 DOI

583 http://dx.doi.org/10.6001/ekologija.v58i3.2533

584 Otis DL, Burnham KP, White DC, Anderson DR (1978) Statistical inference from

585 capture data on closed animal populations. Wildl Monogr 62:1-135. DOI

586 http://www.jstor.org/stable/3830650

587 Patricelli D, Barbero F, La Morgia V, Casacci LP, Witek M, Balletto E, Bonelli S

588 (2011) To lay or not to lay: oviposition of Maculinea arion in relation to Myrmica ant

589 presence and host plant phenology. Anim Behav 82:791-799. DOI

590 10.1016/j.anbehav.2011.07.011

591 Pech P, Fric Z, Konvicka M, Zrzavy J (2004) Phylogeny of Maculinea blues

592 (Lepidoptera: Lycaenidae) based on morphological and ecological characters: evolution

593 of parasitic myrmecophily. Cladistics 20:362-375. DOI 10.1111/j.1096-

$594 \quad 0031.2004 .00031 . x$

595 Pecsenye K, Bereczki J, Tihanyi B, Tóth A, Peregovits L, Varga L (2007) Genetic

596 differentiation among the Maculinea species (Lepidoptera: Lycaenidae) in eastern

597 Central Europe. Biol J Linnean Soc 91:11-21. DOI 10.1111/j.1095-8312.2007.00781.x

598 Pfeifer MA, Andrick UR, Frey W, Settele J (2000) On the ecology of a small and

599 isolated population of the Dusky Large Blue Butterfly Glaucopsyche (Maculinea)

600 nausithous (Lycaenidae). Nota Lepid 23:147-172 
601 Piaggio AJ, Navo KW, Stihler CW (2009) Intraspecific comparison of population 602 structure, genetic diversity, and dispersal among three subspecies of Townsend's big603 eared bats, Corynorhinus townsendii townsendii, C. t. pallescens, and the endangered $C$. 604 t. virginianus. Conserv Genet 10:143-159. DOI 10.1007/s10592-008-9542-0

605 Pollock KH (1982) A Capture-Recapture Design Robust to Unequal Probability of 606 Capture. J Wildl Manage 46:752-757. DOI 10.2307/3808568

607 Pollock KH, Nichols JD, Brownie C, Hines JE (1990) Statistical inference for capture 608 recapture experiments. Wildl Monogr 107:1-97. DOI

609 http://www.jstor.org/stable/3830560

610 Rákosy L, Vodă R (2008) Distribution of Maculinea genus in Romania. Entomol Rom $611 \quad 13: 9-17$

612 Roy DB, Rothery P, Moss D, Pollard E, Thomas JA (2001) Butterfly numbers and 613 weather: predicting historical trends in abundance and the future effects of climate 614 change. J Anim Ecol 70:201-217. DOI 10.1111/j.1365-2656.2001.00480.x

615 Rózsa L, Reiczigel J, Majoros G (2000) Quantifying parasites in samples of hosts. J 616 Parasitol 86(2):228-232. DOI http://dx.doi.org/10.1645/0022-

617 3395(2000)086[0228:QPISOH]2.0.CO;2

618 Schmitt T, Rákosy L (2007) Changes of traditional agrarian landscapes and their 619 conservation implications: a case study of butterflies in Romania. Divers Distrib 620 13:855-862. DOI 10.1111/j.1472-4642.2007.00347.x

621 Settele J, Kühn E, Thomas J (eds) (2005) Studies on the Ecology and Conservation of 622 Butterflies in Europe. Vol. 2. Species ecology along a European Gradient: Maculinea 623 butterflies as a model. Pensoft Publishers, Sofia-Moscow 
624 Sielezniew M, Rutkowski R, Ponikwicka-Tyszko D, Ratkiewicz M, Dziekanska I, 625 Svitra G (2012) Differences in genetic variability between two ecotypes of the 626 endangered myrmecophilous butterfly Phengaris (=Maculinea) alcon - the setting of

627 conservation priorities. Insect Conserv Divers 5:223-236. DOI 10.1111/j.1752628 4598.2011.00163.x

629 Skórka P, Nowicki P, Lenda M, Witek M, Sliwinska EB, Settele J, Woyciechowski M 630 (2013) Different flight behaviour of the endangered scarce large blue butterfly

631 Phengaris teleius (Lepidoptera: Lycaenidae) within and outside its habitat patches.

632 Lands Ecol 28:533-546. DOI 10.1007/s10980-013-9855-3

633 Solmsen N, Johannesen J, Schradin C (2011) Highly asymmetric fine-scale genetic 634 structure between sexes of African striped mice and indication for condition dependent 635 alternative male dispersal tactics. Mol Ecol 20:1624-1634. DOI 10.1111/j.1365636 294X.2011.05042.x

637 Stamp NE (1980) Egg deposition patterns in butterflies: why do some species cluster 638 their eggs rather than deposit them singly? The Am Nat 115:367-380. DOI

639 http://www.jstor.org/stable/2460724

640 Steiner FM, Schlick-Steiner BC, Höttinger H, Nikiforov A, Moder K, Christian E 641 (2006) Maculinea alcon and M. rebeli (Insecta: Lepidoptera: Lycaenidae) - one or two 642 Alcon Blues? Larval cuticular compounds and egg morphology of East Austrian 643 populations. Ann Naturhist Mus Wien, 107B:165-180

644 Steytler SN, Samways MJ (1995) Biotope selection by adult male dragonflies (Odonata)

645 at an artificial lake created for insect conservation in South Africa. Biol Conserv

646 72:381-386. DOI 10.1016/0006-3207(94)00052-R 
647 Sunderland K, Samu F (2000) Effects of agricultural diversification on the abundance,

648 distribution, and pest control potential of spiders: a review. Entomol Exp Appl 95:1-13.

649 DOI 10.1023/A:1003986225443

650 Thomas JA, Clarke RT, Elmes GW, Hochberg ME (1998b) Population dynamics in the 651 genus Maculinea (Lepidoptera: Lycaenidae). In: Dempster JP, McLean IFG (eds) Insect 652 Population In Theory and in Practice. Chapman and Hall, London, pp 261-290. DOI 653 10.1007/978-94-011-4914-3_11

654 Thomas JA, Elmes GW (2001) Food-plant niche selection rather than the presence of 655 ant nests explains oviposition patterns in the myrmecophilous butterfly genus 656 Maculinea. Proc R Soc Lond B 268:471-477. DOI 10.1098/rspb.2000.1398

657 Thomas JA, Elmes GW, Wardlaw JC (1998a) Polymorphic growth in larvae of the 658 butterfly Maculinea rebeli, a social parasite of Myrmica ant colonies. Proc R Soc Lond 659 B 265:1895-1901. DOI 10.1098/rspb.1998.0517

660 Thomas JA, Settele J (2004) Butterfly mimics of ants. Nature 432:283-284. DOI $66110.1038 / 432283 a$

662 Thomas JA, Simcox DJ, Clarke RT (2009) Successful Conservation of a Threatened 663 Maculinea Butterfly. Science 325:80-83. DOI 10.1126/science.1175726

664 Timuş N, Craioveanu C, Sitaru C, Rus A, Rákosy L (2013) Differences in adult 665 phenology, demography, mobility and distribution in two syntopic ecotypes of 666 Maculinea alcon (cruciata vs. pneumonanthe) (Lepidoptera: Lycaenidae) from 667 Transilvania (Romania). Entomol rom 18:21-30

668 Van Dyck H, Oostermeijer JGB, Talloen W, Feenstra V, Van der Hidde A, Wynhoff I 669 (2000) Does the presence of ant nests matter for oviposition to a specialized 
670 myrmecophilous Maculinea butterfly? Proc R Soc Lond B 267:861-866. DOI

$671 \quad 10.1098 /$ rspb.2000.1082

672 Van Dyck H, Regniers S (2010) Egg spreading in the ant-parasitic butterfly, Maculinea

673 alcon: from individual behavior to egg distribution pattern. Anim Behav 80:621-627.

674 DOI 10.1016/j.anbehav.2010.06.021

675 Van Swaay C, Cuttelod A, Collins S, Maes D, Munguira ML, Šašić M, Settele J,

676 Verovnik R, Verstrael T, Warren M, Wiemers M, Wynhoff I (2010) European Red List

677 of Butterflies. Luxembourg: Publications Office of the European Union. DOI

$678 \quad 10.2779 / 83897$

679 Van Swaay C, Warren M (1999) Red Data Book of European Butterflies (Rhopalocera).

680 Nature and Environment 99, Council of Europe Publishing, Strasbourg

681 Vrezec A, Ambrožič S, Kapla A (2012) An overview of sampling methods tests for

682 monitoring schemes of saproxylic beetles in the scope of Natura 2000 in Slovenia. In:

683 Saproxylic beetles in Europe: monitoring, biology and conservation. Birografika Bori,

684 Ljubljana, pp 73-90

685 Vulinec K (1990) Collective security: Aggregation by insects as a defense. In: Evans

686 DL, Schmidt JO (eds) Insect defenses. Adaptive mechanisms and strategies of prey and

687 predators. State University of New York Press, Albany, pp 253-287

688 WallisDeVries MF, Raemakers I (2001) Does Extensive Grazing Benefit Butterflies in

689 Coastal Dunes? Restoration Ecol 9:179-188. DOI 10.1046/j.1526-

690 100x.2001.009002179.x

691 Way MJ, Heong KL (1994) The role of biodiversity in the dynamics and management

692 of insect pests of tropical irrigated rice-a review. Bull Entomol Res 84:567-587. DOI

$69310.1017 /$ S000748530003282X 
694 White GC, Burnham KP (1999) Program MARK: Survival estimation from populations

695 of marked animals. Bird Study 46:120-138. DOI 10.1080/00063659909477239

696 Wiklund C (1984) Egg-laying patterns in butterflies in relation to their phenology and

697 the visual apparency and abundance of their host plants. Oecologia 63:23-29. DOI

$698 \quad 10.1007 / \mathrm{BF} 00379780$

699 Witek M, Barbero F, Markó B (2014) Myrmica ants host highly diverse parasitic

700 communities: from social parasites to microbes. Insectes Sociaux 61:307-323. DOI

$701 \quad 10.1007 / \mathrm{s} 00040-014-0362-6$

702 Witek M, Nowicki P, Sliwinska EB, Skórka P, Settele J, Schönrogge K,

703 Woyciechowski M (2010) Local host ant specificity of Phengaris (Maculinea) teleius

704 butterfly, an obligatory social parasite of Myrmica ants. Ecol Entomol 35:557-564. DOI

705 10.1111/j.1365-2311.2010.01213.x

706 Wynhoff I, Bakker RB, Oteman B, Arnaldo PS, Van Langevelde F (2015) Phengaris

707 (Maculinea) alcon butterflies deposit their eggs on tall plants with many large buds in

708 the vicinity of Myrmica ants. Insect Conserv Divers 8:177-188. DOI

709 10.1111/icad.12100

710 Yamamura K, Yokozawa M, Nishimori M, Ueda Y, Yokosuka T (2006) How to

711 analyze long-term insect population dynamics under climate change: 50-year data of

712 three insect pests in paddy fields. Popul Ecol 48:31-48. DOI 10.1007/s10144-005-0239-

7137

714 
715 Table 1. Basic parameters of the investigated Maculinea alcon 'cruciata' population as 716 revealed by the MRR study (95\% confidence intervals in brackets).

\begin{tabular}{|c|c|c|c|c|}
\hline & $\begin{array}{l}\text { Captured } \\
\text { individuals }\end{array}$ & $\begin{array}{l}\text { Seasonal } \\
\text { population }\end{array}$ & $\begin{array}{l}\text { Survival rate } \\
\qquad\left[\text { day }^{-1}\right]\end{array}$ & $\begin{array}{c}\text { Adult lifespan } \\
\text { [days] }\end{array}$ \\
\hline Males & 152 & $382(305-496)$ & $\begin{array}{c}0.63(0.57- \\
0.69)\end{array}$ & $2.2(1.8-2.8)$ \\
\hline Females & 73 & $317(219-480)$ & $\begin{array}{c}0.57(0.34- \\
0.77)\end{array}$ & $1.8(1.0-3.8)$ \\
\hline All & 225 & $699(565-884)$ & $\begin{array}{c}0.62(0.56- \\
0.68)\end{array}$ & $2.1(1.8-2.6)$ \\
\hline
\end{tabular}

717 
718 Table 2. Spearman rank correlations ( $\mathrm{n}=22$ in all cases) between the number of eggs

719 present and the number of newly laid eggs on host plants on different capture dates.

720 Statistically significant values are bolded.

\begin{tabular}{lll} 
capture date & Spearman $\mathrm{r}$ & $\mathrm{p}$ \\
& & \\
& -0.73 & $\mathbf{0 . 0 0 1}$ \\
22.06 & -0.21 & 0.731 \\
26.06 & -0.51 & $\mathbf{0 . 0 0 6}$ \\
30.06 & -0.89 & $<\mathbf{0 . 0 0 1}$ \\
04.07 & 0.04 & 0.861 \\
08.07 & -0.74 & $<\mathbf{0 . 0 0 1}$ \\
12.07 & -0.91 & $<\mathbf{0 . 0 0 1}$ \\
\hline
\end{tabular}

721 
722 Table 3. The supported models according to the results of the automated model 723 selection procedure. See the text for the explanations of the model variables.

\begin{tabular}{|c|c|c|c|c|c|}
\hline Model & $\underline{\mathrm{df}}$ & $\underline{\log \mathrm{Lik}}$ & $\underline{\mathrm{AICc}}$ & $\underline{\mathrm{AICc}}$ & $\underline{\text { weight }}$ \\
\hline $\mathrm{PC} 1+\mathrm{PC} 2$ & 5 & -119.61 & 249.37 & 0.00 & 0.25 \\
\hline PC1+PC2+Height & 6 & -119.30 & 250.80 & 1.43 & 0.12 \\
\hline PC1 & 4 & -121.47 & 251.03 & 1.66 & 0.11 \\
\hline Cover+PC1+PC2 & 6 & -119.51 & 251.23 & 1.87 & 0.10 \\
\hline Density+PC1+PC2 & 6 & -119.56 & 251.33 & 1.96 & 0.10 \\
\hline Density+PC1 & 5 & -121.14 & 252.43 & 3.06 & 0.06 \\
\hline Cover+PC1+PC2+Height & 7 & -119.16 & 252.61 & 3.27 & 0.05 \\
\hline PC1+Height & 5 & -121.28 & 252.72 & 3.35 & 0.05 \\
\hline Density+PC1+PC2+Height & 7 & -119.26 & 252.79 & 3.43 & 0.05 \\
\hline Cover+PC1 & 5 & -121.37 & 252.89 & 3.52 & 0.05 \\
\hline Cover+Density+PC1+PC2 & 7 & -119.46 & 253.20 & 3.84 & 0.04 \\
\hline
\end{tabular}


726 Fig. 1. Dynamics of male and female adult butterflies throughout the study period based 727 on mark-recapture estimates. Error bars represent $95 \%$ confidence intervals.

728 Fig. 2. The (a) outline of the study site and the (b) distribution of male (black) and 729 female (white) butterfly captures (recaptures included).

730 Fig. 3. The frequency distribution of eggs on host plant shoots.

731 Fig. 4. Temporal dynamics of eggs laid on the host plants during the flight period. Error 732 bars represent Standard Deviations.

733 Fig. 5. The number of butterfly eggs laid on host plants in relation to the host plant

734 height and number of leaves (the circle area is proportional to the number of eggs laid). 


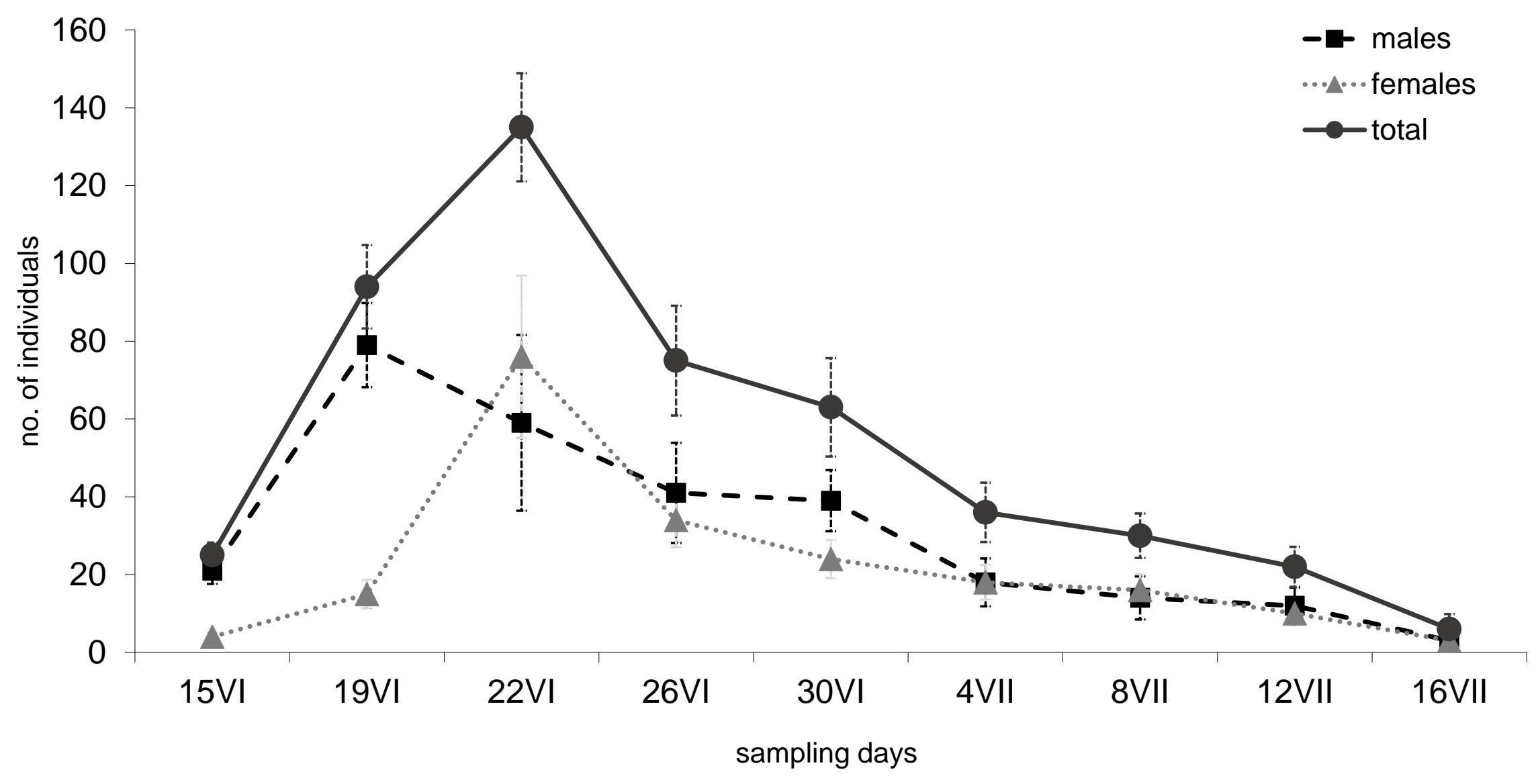





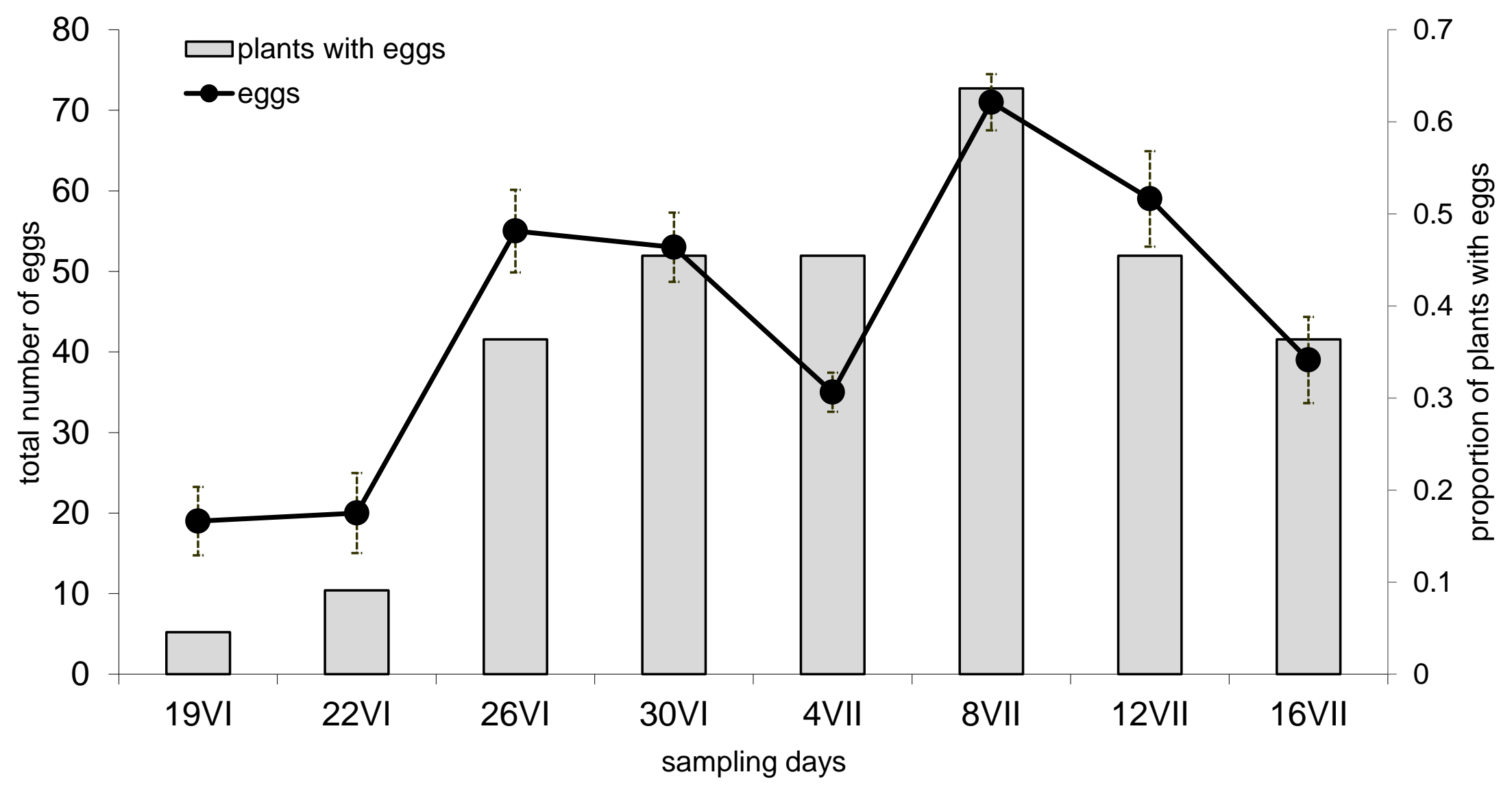




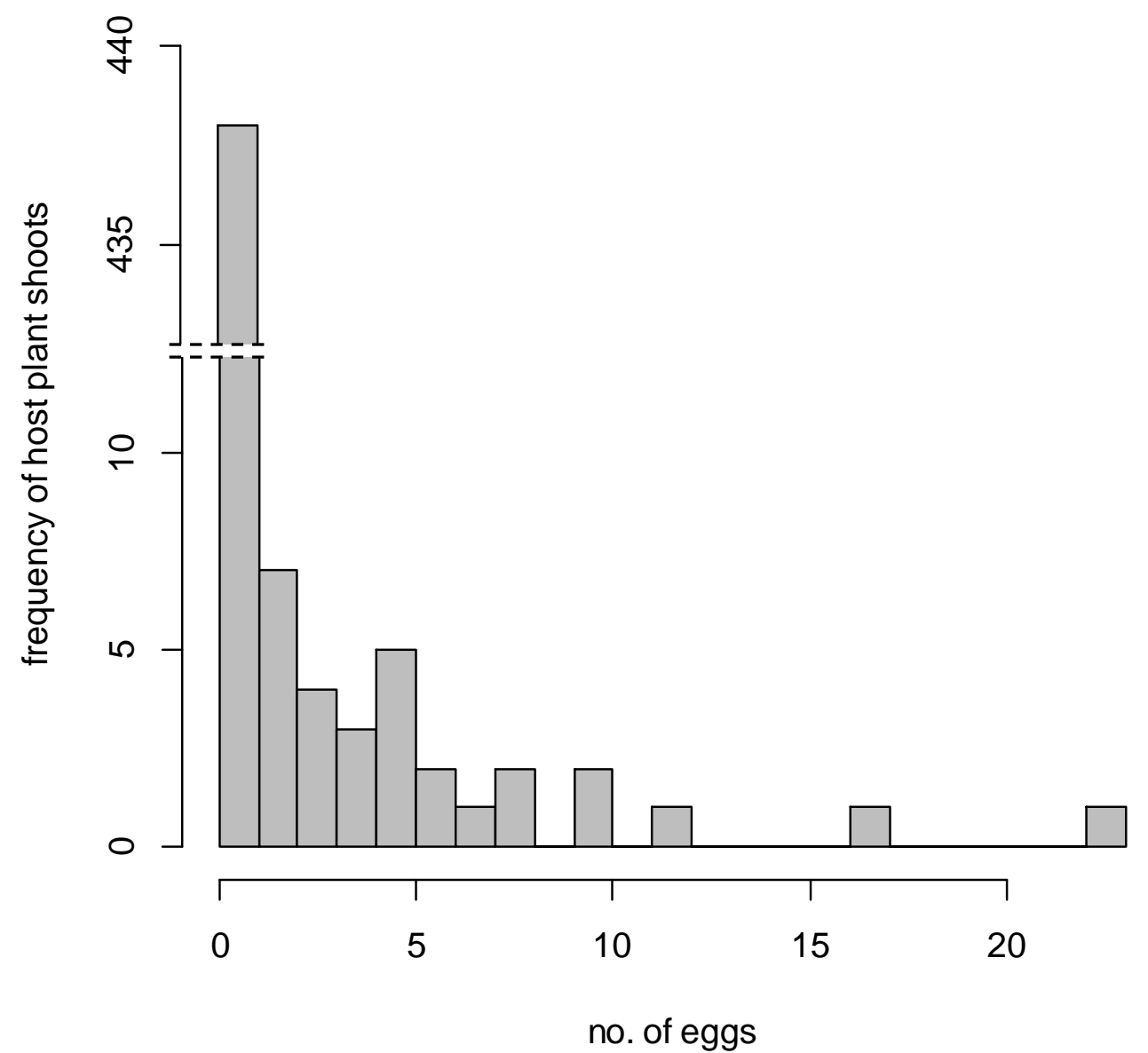




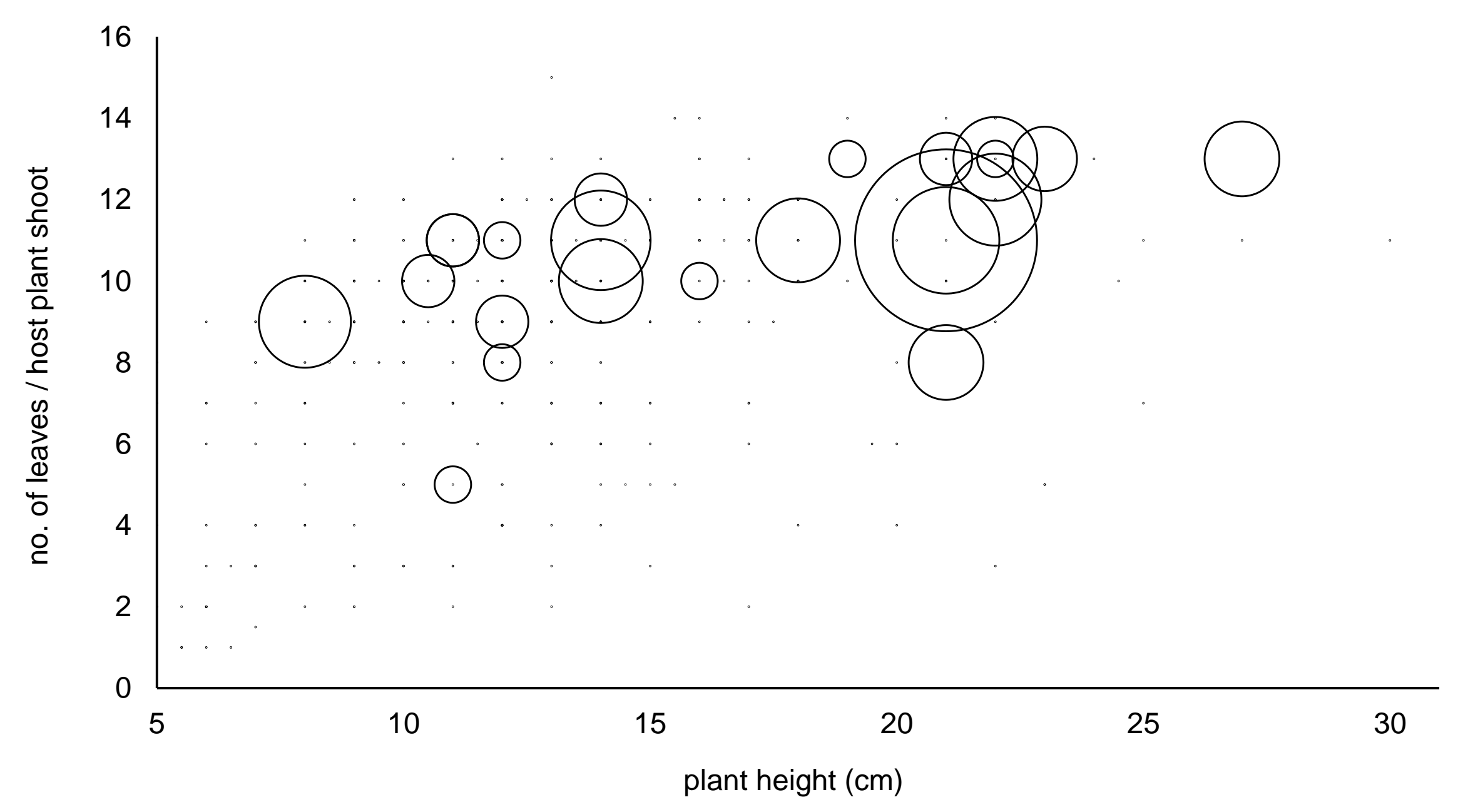

